\title{
Concilium Ophthalmologicum Universale
}

A meeting of the International Council of Ophthalmology was held in Paris on June 2021, 1953. There were present-Duke-Elder (Great Britain, President), Berens (U.S.A., Vice-President), Hartmann (France, Secretary), Amsler (Switzerland, Treasurer), Bailliart (France, President of the International Association against Blindness), MacCallan (Great Britain, World Organization against Trachoma), Alvaro (Brazil), Bietti (Italy), Charamis (Greece), Duggan (India), Ehlers (Denmark), Law (Great Britain), Löhlein (Germany), Samuels (U.S.A.), Stuart Ramsay (Canada), Velter (France), Fritz (Secretary for Internationalization), Copper (Secretary for the Index Ophthalmologicus).

Apart from routine matters the main business of general interest was as follows:

(1) XVII International Congress of Ophthalmology.-It was unanimously decided that the scope of this Congress might be extended to become a Canadian-American Congress to be held from September 10-17, 1954: meetings on September 10 and 11 to be held in Canada, and (as previously arranged) meetings on September 12-17 in New York. Full particulars will be published in the immediate future by the Executive Committee of the Congress in the U.S.A.

The Council accepted the invitation of the Council for International Organizations of Medical Sciences to hold a Symposium on the subject of Glaucoma in association with this Congress.

(2) International Standards. - The reports of the Commissions dealing with international standards for Colour Vision, Tonometry, and the Visual Requirements for various forms of Transport were finally accepted. Adequate standardization of the Light Sense was considered impracticable and the activities of this Commission were closed. The Commission dealing with the International Standardization of Visual Acuity (Optotypes) was given a further year to produce an agreed report. An interim report was received from the Commission studying ophthalmological education in various countries.

(3) Index Ophthalmologicus.-Arrangements were made for the publication of the Index and its sale at the XVII International Congress. It is proposed to make this Index more comprehensive and useful than hitherto; it will contain the names and addresses of ophthalmologists in most countries of the world as well as a list of ophthalmic hospitals, journals, and other information of ophthalmic interest, and a résumé of the activities of the Council.

(4) International Ophthalmological Dictionary.-It is hoped that this Dictionary of Ophthalmological Terms in English, French, German, Spanish, Italian, and Latin will be available at the XVII International Congress.

(5) Regulations.-New Statutes governing the International Federation of Ophthalmological Societies, the International Council of Ophthalmology, and the International Congresses were finally adopted by the Council for presentation to the meeting of the Federation to be held in Canada in 1954.

(6) Gonin Medal.- The Council awarded the Gonin Medal to be presented at the opening ceremony of the XVII International Congress to Sir Stewart Duke-Elder.

(7) Finance.-It was decided that the surplus money from the XVI International Congress should be used to assist those who would make a contribution to the XVII International Congress but who would be precluded from attending it from financial reasons. The distribution of the money was entrusted to the President, Secretary, and Treasurer of the International Council.

(8) Council.-Löhlein's resignation was regretfully accepted and Thiel was elected in his place.

The next meeting of the Council will be held in Canada in September, 1954.

EDWARD HARTMANn (Secretary)

2, Avenue Ingres, Paris, XVIme.

\section{HONOURS}

Mr. A. B. NutT, F.R.C.S., of Sheffield, has been co-opted to the Council of the Royal College of Surgeons of England as the representative of Ophthalmology for 1953-1954. 